\title{
How the Word "Zionist" Functions in Antisemitic Vocabulary
}

\author{
David Hirsh
}

\begin{abstract}
This paper is a partial response to the intuitive claim that hostility to "Zionists" is not hostility to Jews and so is not antisemitic. It examines ways in which the terms "Zionist" and "Zionism" themselves feature in antisemitic text and discourse. It argues that antisemitism should be understood as a complex phenomenon that is observable in the social world only with some difficulty, and that understanding should begin in a consideration of that observation data. This paper is critical of the opposite method, which sees the observable world only through pre-existing a priori concepts; an example of this is the construction of the concept of Zionism as essentially racist. This method treats observable phenomena, like racism, as inevitable manifestations of the predetermined concept, Zionism. Zionism, and its relationship to racism, should be understood after observing their actuality in the world, not as a priori definitions, which then structure what is observed. Much understanding of Zionism therefore adds a methodological double standard to the double standards of judgment, which have already been well described. The paper draws on a number of case studies, that is, actualizations of Zionism and antisemitism in the existing world: the opposition to David Unterhalter's nomination to the Constitution Court in South Africa; the antizionist construction of Zionism as racism without the consent or the collaboration of people who self-identify as Zionists; statements circulating in academia that define the communities of scholarship and of morality in ways that exclude most Jews; the designation of Israel as apartheid. The paper concludes with a word on how antizionist nostalgia resists facing the material changes to Jewish life, which were enforced during the twentieth century.
\end{abstract}

Keywords: anti-Zionism, antizionism, antisemitism, anti-Semitism, Israeli apartheid, Zionism

\section{PREFACE: HOW PEOPLE TALK ABOUT "ZIONISTS"}

A message from Facebook in 2014: "We reviewed your report of 'Death to Zionist baby killer Israeli Jews' . . . and found it doesn't violate our community standards." ${ }^{\prime}$ And in May 2021, a post stating that "Israel is the home of the baby killer" and referring to "baby killing Zionists" was judged not to be in violation of Facebook's community standards. ${ }^{2}$

For a thousand years, wherever they have lived, Jews have been periodically accused of murdering non-Jewish children. This blood libel originates in antisemitic interpretations of Christian theology. The accusation is that Jews reenact the killing of G-d on the bodies of innocent children and that they do so not for gain but out of pure evil. "The Jews" have never murdered children, but the blood libel as a staple trope of antisemitism has resulted in the murder of Jewish children.

In May 2021, Israel was involved in a military conflict with Hamas in Gaza. Palestinian civilians, including children, died in this conflict. Israel says that its technical capacity to hit military targets in urban warfare while minimising 
deaths and injuries to civilians, even when those targets are deliberately positioned close to civilians, is well developed. Israel's enemies say that Israel is committing genocide, bombing the Palestinians and murdering Palestinian children.

In March 2016, a local politician in Britain was suspended from membership of his party for having shared a Facebook post, which said that schools do not teach children about the crimes of colonialism: "Your school education system only tells you about Anne Frank and the six million Zionists that were killed by Hitler." ${ }^{3}$

In May 2021 a senior Iranian military officer advised Zionists in a speech "to go back and buy back the homes they sold in Europe, America and elsewhere when they moved, before they become more expensive." ${ }^{3}$ It is not reported whether he offered any advice to Zionists who fled Iran after the Ayatollahs came to power in 1979.

In 2019 an image was shared on Facebook of a scientist looking through his microscope at a red Star of David. The tweet said "Zionism," and the image said, "This is the worst cancer I've ever seen." In the same year there was a tweet citing British politician George Galloway as an authority, which explained the relevant distinction: "Zionists are all blood drinking monsters who secretly control the world." 6

In 2017 a Twitter user offered some advice: "they try to portray Arabs as 'Jew haters' but as long as you distinguish between a Jew and a Zionist, you're good."7

In May 2003, a senior Labour MP in Britain, Tam Dalyell, accused Prime Minister Tony Blair of "being unduly influenced by a cabal of Jewish advisers." ${ }^{8}$ Paul Foot, a prominent socialist journalist, leapt to Dalyell's defence: "obviously he is wrong to complain about Jewish pressure on Blair and Bush when he means Zionist pressure."

In May 2021, somebody tweeted an image of an Israeli police officer with the text "where are the gas chambers when you need them?" She was challenged: "Are you actually calling for gas chambers?" "Yes," she responded, "against Israeli forces (not Jews) who are committing war crimes." 10

\section{INTRODUCTION}

This paper notices that people who are hostile to Zionism have given the word "Zionism" a meaning that reflects their own hostility. "Zionism" is treated as the enemy of all democratic values and as the legitimating ideology of Israel, which is thus understood as the actualization of the rejection of democratic values in the world. In this understanding of Zionism, antizionism is a just cause and is the opposite of antisemitism, which, like Zionism, is a kind of racism.

But this is an inversion of reality. By portraying the overwhelming majority of Jews in the world as the enemies of all that is good, antizionism reconstructs a way of thinking that was thought, at least in the West, to have been permanently discredited by the experience of the Shoah. Yet the use of Jews to represent the idea of "enemy of the people" persisted after the Shoah in the Soviet Union and in places where that version of communism was influential. And, even after the Shoah, some people in the great cities and the newly emerging states of the Middle East continued to regard Jews as alien and threatening.

Antizionism imposes its own essentialist conception of Zionism, constructed as racism, onto the actually existing and diverse political identities of Jewish women and men. This imposition is crudely intrusive and it does not accurately reflect the complex realities of Jewish political cultures.

The apparently disparate arguments, narratives, and themes discussed in this paper are woven together by a common thread of methodological critique. Antizionism is based on what the Marxists used to call an "idealist" foundation. It understands Israel as the earthly manifestation of Herzl's putatively racist idea, rather 
than as the historical product of the material convulsions of history since the late nineteenth century, especially as they have related to Jewish life.

Antizionism is essentialist. It understands every material reality in Israel as though it was caused by Israel's putative inner essence. Antizionism also defines antisemitism by reference to concepts in their abstract forms, rather than by studying the dialectical, complex and contradictory relationships between those concepts and the material world to which they relate. Antizionism adds a methodological double standard to the more usually noticed double standards by which it judges Israel by unique measures.

This paper looks at how the relationships between antisemitism and antizionism have been narrated, understood, and contested. It analyses antizionist opposition to David Unterhalter's nomination to the Constitution Court in South Africa, and in particular the way that opposition defined Unterhalter's political identity without his consent or collaboration, and in a wholly hostile that defined him, unjustly, as being profoundly in violation of the values of his country and his profession. The paper looks at how a social science method might understand the contradiction between Israel's tasks to be Jewish and to be democratic. It looks at some of the meanings and identities that "Zionism" has had for the Jews who embrace it for themselves. The paper looks at some of the recent statements that have been circulating amongst antizionist academics during the 2021 conflict between Israel and Hamas. And it argues that those statements may be understood to constitute antisemitic loyalty tests.

Saying that Israel is like apartheid South Africa is another way that Zionism has been defined as though it was something disgraceful in its essence. The Israel-apartheid analogy first emerged in the self-serving Soviet propaganda of the Cold War and was given an important boost at the 2001 World Conference against Racism in Durban. The analogy has gained wider acceptance in recent months, crystallising a more general acceptance of antizionism and signifying a marginalization of opinion that hopes for a peace between Israel and the Palestinians. This paper looks at the apartheid analogy and finds, again, that the ostensibly straightforward conceptual framework has significant difficulty mapping onto the real world.

Zionism was conceived as a national liberation movement for Jews. Herzl wanted to find a way for Jews to escape the oppression of antisemitism, in Europe, in Russia, and across the Middle East, and to live free, as other people live free.

But in our day the word "Zionism" itself often functions as an antisemitic curse word, which hurts and discredits Jews. When Jews are denounced as "Zionist," they are being accused of thinking they are better than everyone else and of supporting racism. It is a repackaging of old antisemitic understandings of the term "Chosen people," a term that was already in Christian traditions a repackaging of nuanced, complex, and developing ways in which Jews thought about themselves. The word "Zionism" frequently constructs Jews as participating in dishonest global networks, conspiracies of lies and propaganda, in their own selfish interest. It positions most Jews as though they are in alliance with a formidable global system of oppression, sometimes called "modernity," or "capitalism," or "imperialism."

The word "Zionism" in antizionist usage conveys a familiar mixture of contempt and fear, as have previous words that have been used against Jews. It does this in a world in which the old words and languages of Jew-hatred have appeared discredited. New movements against Jews have always begun by discrediting previous ones. It is only in our day, and it is a terrible irony of history, says every new movement against Jews, that Jews have actually started to behave in the ways that previous antisemitic 
movements had dishonestly alleged. ${ }^{11}$ The word "Zionism," which still resonates for many people as an expression of hope for Jewish survival and liberation, has also become a weapon in the antisemitic arsenal.

Many scholars of antisemitism have dispensed with the hyphen in "anti-Semitism." This is because there is no "Semitism," which antisemitism opposes. Antisemitism does not in the first place fear and hate the existing diversity of Jewish men and women. What it regards as being central to all that is bad in the world is its own conception of "the Jews"; a conception that it has invented, even if it has built it partly out of elements and tropes, which it has resurrected and reanimated from older antisemitic movements. Only then is the fictional and demonic notion of "the Jews" thrust upon flesh-and-blood Jewish people; and only then does it punish them for the evils of its own imagination; evils that are, in fact, projections of its own fantasy world, and only tangentially related to actual facts about actual Jews.

Antizionism is written without a hyphen for the same reason. The "Zionism," against which the antizionists build their worldview, is constructed out of their own imaginations; and it also draws upon older antisemitic elements and tropes. That Zionism, meaning racism, meaning apartheid, symbolizing everything bad in the world, is invented by antizionists and is only tangentially related to the actual histories and realities of Zionism, or to the ways in which actual Jews relate to Israel.

\section{ANTIZIONISM AND ANTISEMITISM}

This paper relates centrally to one significant form of antisemitism, that is, the form that appears as hostility to Israel or to Zionism. It is about how the word "Zionism" itself has come to convey antisemitic meaning and emotion. That is to say, it is often a key word in antisemitic discourse, or ways of thinking. The word "Zionism" often appears in speech and writing that articulates hostility or threat to Jews, creates hostile environments for Jews, and is taken to license exclusions of Jews or violence aimed at Jews.

One standard antizionist response to this suggestion is the indignant insistence on an absolute distinction between antizionism and hostility to Israel, on the one hand, and antisemitism, which is hostility to Jews, on the other. antizionism is held to be a necessary element of a wider anticolonial, antiracist, and egalitarian worldview, while antisemitism, it is agreed, is wholly unacceptable and is similar to racism. Yet it should be remembered that the left-wing tradition of antizionism, which professes unconditional opposition to antisemitism, is only one tradition. In the real world that tradition finds itself in a broad alliance with antisemitic movements that do not find the distinction between hostility to Israel and hostility to Jews to be of much significance. Even when the "love antizionism, hate antisemitism" position is asserted in good faith, antizionism as it becomes actualized in the world often fails to transcend its own antisemitic roots, alliances, logics, and predictable outcomes. Good faith cannot on its own nullify the menace and the injustice of objective social structures of power, which are external to any particular person, be they wellmeaning or not.

We should not begin by discussing antisemitism and antizionism in the abstract. We should not begin by discussing hypothetical elements of rhetoric that we have invented as thought experiments. We should begin with antisemitism as it appears in the world and in context. The contexts of antisemitic speech and texts are diverse and they can change. They are related to particular national cultures, with similarities and differences from each other, but which mutually interconnect and influence each other. There are different religious cultures, again, with continuities, discontinuities, and interchanges between. And there are distinct political cultures, some of which are mutually 
hostile, but which can overlap and share assumptions or elements of rhetoric between them. And then there is political expression, which is difficult to recognise as coming from this or that specific political tradition. Sometimes, for example, it is impossible to tell whether an element of antizionist rhetoric is right-wing, left-wing, or Islamist.

So we should not start with the simple and the abstract but with the swirls of discourse as they actually appear in the world. In those swirls, in that real world, in those infinite interconnections, we are interested in the forms that antisemitism takes, and how we can recognise it.

This paper is not going to tell you whether campaigns to boycott Israel, or the Israelapartheid analogy, or hoping for a world without Israel, are antisemitic in the abstract, inside the head of a thinker. But it will show you that these movements, practices, and rhetorics are key parts of the antisemitism that actually exists in the world.

Social media is emphatically part of the world and social media is an important sphere in which antisemitism is circulated and in which people are taught to think in antisemitic ways. There is a common-sense understanding of social media as not "real." We know what it means when somebody tells us to stop spending so much time on Twitter and to spend more time in the real world. Social media may be a virtual world, it may be non-material in a sense. But the interactions, emotions, structures of power, bullying, relationships, networks, and exclusions that happen online are real. Antisemitism online corrupts real people; it excludes and harms Jews; it mis-educates; it pollutes ways in which people think in the world outside of the internet. Even when accounts are anonymous, where there are "sock puppets," where people are pursuing fantasies about who they would like to be, online discourse is still an interaction between real human beings, or aspects of real human beings.

\section{ANTIZIONISM DEFINES ZIONISM WITHOUT THE PARTICIPATION OR THE CONSENT OF THE PEOPLE IT DESIGNATES AS ZIONIST}

Zionism, according to United Nations General Assembly Resolution 3379, adopted November 10,1975 , is "a form of racism." ${ }^{12}$ By this definition, Zionism is an ideology of evil, in the same sense that racism is evil. Zionism is often held to be similar to other ideologies generally recognized as evil, such as colonialism, Nazism, and apartheid. If Zionism is understood in this way, it follows that Israel must be understood as Zionism's racist, and so evil, actualization. In this understanding, the racist ideology constructed the racist material reality. Zionism constructed the racist state, which commits racist acts, and which enforces racist oppression.

Zionism, according to the Judicial Service Commission of South Africa, in a media statement of 4 May 2021, "is viewed as a discriminatory form of nationalism and potentially in conflict with the values contained in the South African Constitution." ${ }^{13}$ That view was advocated by the Boycott, Divestment, and Sanctions (BDS) Coalition, which opposed the nomination of Judge David Unterhalter for the Constitution Court. It said that he had served on the South African Jewish Board of Deputies (SAJBD). SAJBD is an umbrella institution of the Jewish community in South Africa. The BDS Coalition said that the Board

serves as a conservative organisation that supports and minimizes the actions of the Israeli apartheid state, much like the Broederbond did with respect to apartheid South Africa. The SAJBD has supported the Zionist state's brutal oppression of the Palestinian people. . . . It is disingenuous to reject apartheid in South Africa yet be a defender of Israeli apartheid. ${ }^{14}$

The Afrikaner Broederbond was a white supremacist organisation, which supported the racist system of apartheid in South Africa. The BDS argument was that Unterhalter had served on the 
Board, the Board was Zionist, meaning pro-apartheid and racist, so Unterhalter was pro-apartheid and racist, and so his values were incompatible with the those of his wider community, his nation.

It is clear from this example how the distinction between hostility to Zionists and hostility to Jews might not be as clear in the world as it seems to be in the minds of antizionists. The truth about the Board of Jewish Deputies in South Africa is that it is a broad representative institution of the Jewish community. That Unterhalter had served on the board was evidence of his participation in his community, not evidence of his Zionism. And even if it was evidence of his Zionism, the ways in which Jews embrace and construct their own political identities are diverse. Yet no Zionist defines their own Zionism as racism. The antizionist definition of Zionism as racism is hostile and it is thrust upon Jews without their consent or their collaboration. It is BDS that defines South African Jews as racist supporters of apartheid. It is BDS that defines South African Jews, therefore, as people who are in profound violation of the values of their country. Defining Zionism and Israel as racist reflects on Jews in general, who are assumed to support Zionism and Israel.

It is fundamental to antiracist and sociological understandings of racism that it is racism that defines "race." There is infinite human diversity among human beings, but some kinds of biological differences are endowed with huge social significance. It is the social process of giving meaning to inherently insignificant biological distinctions that constructs "race." That explains the scare quotes. "Race" is not something that is found in nature, and that is then subjected to discriminatory treatment; it is itself constructed by discriminatory beliefs and associated networks of power.

There is no problem with an identity that people embrace for themselves, that they come to by living their lives, that works well for them in the social context in which they find themselves, that relates to their families and to their communities; a positive, life-affirming understanding of who they are. It is not at all the same, for example, as the kind of Black identity that may be ascribed to a person by a racist cop as they drive their car in an unfamiliar neighbourhood, or the kind of Blackness that may be ascribed to a person as they walk down a lonely street at night by a gang of hostile White kids, or the kind of Blackness that may be ascribed to a person by somebody conducting a job interview.

By analogy, it is antizionism that defines most Jews as Zionist. And the Zionism thus ascribed to Jews is understood as a form of racism. Antizionism does not allow Jews, individuals or communities, to define their own identities. It defines their Zionism for them, against their will, and without consultation. It defines Zionism as racism and as support for apartheid. In so doing it defines most Jews as alien to any decent community of human beings.

Antizionism does offer an exemption for "exceptional Jews" who are willing to denounce Israel using the precise terms, which are specified. But most Jews will never accept this offer to outsource the articulation of their own identities to a movement that has so little understanding of them, and so much hostility towards them.

It is the way that antizionism invents the Zionism of Jews, against their will and without their participation, which explains why the word is written without a hyphen. Antisemitism is not a movement against something that exists, called "Semites" or called Jews; it is a movement against a notion of "the Jews," which it itself has invented. And antizionism is a movement that similarly invents and imposes onto Jews the Zionism against which it defines itself.

Antizionism goes on to define a whole worldview on that hostile and largely fictional foundation. It makes an "-ism” out of opposition to the Israel that it imagines and then describes. The worldview is constructed around a picture of Zionism that has only an obtuse similarity to 
the diverse Zionisms by which Jews understand their own relationships to Israel.

Antisemitism always positioned its own notion of "the Jews" at the center of everything bad in the world. Antizionism's propensity to universalize its Zionism, or its picture of Israel, as the "other" of good things, is not so different. It universalizes Israel and Zionism as symbols of oppression; as pioneers of technologies of surveillance and occupation; as controlling news, culture, Hollywood, and governments around the world; as the keystone of a global system of imperialism; as standing between the world and progress or the world and socialism; as exporting and inciting racism and Islamophobia worldwide; as the force that taught the police in Minneapolis how to use deadly force against African American men.

\section{ANTIZIONISM AS A SIMPLIFYING ESSENTIALISM IMPOSED ON A COMPLEX AND CONTRADICTORY REALITY}

The definition of Israel as racist and evil is essentialist. It is not a claim about what Israel does here, or does not do there, it is a claim about the essence of the idea of Israel and the essence of the material reality of Israel. If Israel is racist in its essence, there cannot be an Israel in which people meaningfully campaign against racism without campaigning against the existence and legitimacy of the state itself.

The standard antizionist method is to describe racist things that Israel does or racism that happens in Israel. The descriptions may be true, exaggerated, one-sided, or untrue; or they may be mixtures of those elements. The racism is presented both as being caused by the racist essence of Israel and as being new proof of the racist essence of Israel.

Palestinians have specific experiences of racism in Israel, and they have specific experiences of racism at the hands of Israeli forces, in particular in the West Bank and Gaza. They have other experiences of Israel and Israelis, too. Antizionism interprets Palestinian experience only as manifestations of Israel's racist essence. It constructs Palestinian opposition to racism as being fundamentally pointless. And it constructs any Arab or Palestinian identity in relation to Israel that is not compatible with antizionist essentialism as a kind of "false consciousness." Antizionism thrusts identity onto Arabs and Palestinians with as little care for the complexities and diversities of their lived experiences, and the ways people make sense of those for themselves, as it does with Jews.

The "Zionism is racism" case is simple: a state that is defined as a state for Jews or a Jewish state, and not a state for all its citizens, must be racist. It must prioritize the interests, the identity, and the rights of Jews, on the basis of their ethnicity or religion, over those of non-Jewish citizens. The assumption is that Israel can only be racist against Arabs; and it could only have been founded on the settler-colonial theft of land, which rightly belongs to "indigenous" Palestinians. Antizionism does not allow the possibility that Jews may be indigenous, or that Arabs may be migrants. It has nothing coherent to say about where in the world Jews are rightly considered indigenous. And the division of human beings into those who are authentically connected to the land, and others who are not, has not always ended well.

An effort to understand Israel inspired by a genuine social science method would start by looking at the reality of Israel in its complexity and in the context of its story. For sure, there is racism. There are cultural, political, and institutional structures of racism. These are in some ways similar to, and in some ways different from, what you would see if you look at what happens anywhere else on the planet. There is quite a lot of racism in Israel because Israel is a society, which has been in a number of related conflicts with its neighbours, relentlessly, since before it existed as a state. Social science observes the world carefully and then it tries to make sense of what it observes. But if you define Israel in advance as racist, and evil in its essence, then things that you observe can only be made sense 
of in terms of your preexisting understanding of its necessary and eternal characteristics.

The antizionist case is that Israel cannot be both Jewish and also democratic for all its citizens. Israel's Jewishness, says antizionism, must take precedence over its democracy.

But there is a more interesting way of thinking about the contradiction at the heart of Israel between its Jewishness and its democracy. It is a way of thinking that is more in keeping with the ways in which we usually think about social life in general, and nations and states in particular. Social life is always contradictory and complex, it is never simple and binary. We know that democratic citizenship is always equal in abstract principle but we also know that there are all kinds of structures of power, which cut across nations, such as class, gender, religion, and racism, which also distribute access to economic, legal, and social power unevenly. States are always sites of mediation between contradictory interests, principles, and realities.

History gave Israel contradictory obligations. Or it might be more straightforwardly said that Israel has given itself, or has accepted, contradictory obligations. One is to be a Jewish state, a means of self-defence for Jews, many of whom felt that they had been taught by history that they could not rely on other states to guarantee their rights. Israel is not only a state for Jewish Israelis, but also a state for Jews period. It accepted the obligation of being open to offer asylum to Jews who may need it in the future, because Jews remember times in history when they could not find asylum anywhere on the earth. Hence, embedded at the heart of the state of Israel is the law of return, which guarantees citizenship to any Jew who claims it. Of course, any future Palestinian state would have a similar law of return. Another obligation, which Israel accepted, which also followed from its own diverse stories, was to be a democratic state, a state that guarantees the rights of every citizen, a state that treats minorities fairly.

So, the task of understanding is not to look judgmentally from afar and declare that fulfilling these contradictory obligations is impossible. In any case, law, justice, equality, and democracy, as well as national community, are all, in their abstract perfect forms, utopian. The task is to look at Israel and think about how well it has fulfilled its contradictory obligations. The task of understanding is not to begin with an essentialist idea in our heads and to interpret what happens in the world according to our prior truth. The task is to look at reality and to judge how well Israel has functioned to guarantee Jewish survival, how well it has functioned as a life-raft state, and how well it has functioned as a democracy. How well has it conducted fair elections? How close has it come to the ideals of the rule of law? Has the separation of powers functioned as well as it might, and has an independent sphere of civil society and individual liberty been protected by the state? How much harm have the military necessities imposed on Israel, and the way it has addressed them, done to its civil culture and to its democratic functioning?

The point is that these are open questions, both empirically and conceptually. The answers are likely to be that it has done well here, but not so well there, it has done well in this aspect and not so well in that. And this way of looking also opens up thinking about how it might do better, and how it might guard against repeating its failures.

In fact, the practice of defining Zionism as essentially bad because it must necessarily privilege its Jewish obligations over its democratic obligations fits into a bigger tradition of binary thinking about nationalism. There has always been a temptation to define some nationalisms, and perhaps then some nations, as good and others as bad. Some have made a distinction between imperialist nationalism as racist and aggressive, while anti-imperialist nationalism is the organisation of just struggles for selfdetermination. Some have made a similar distinction between oppressed and oppressor nations, or between civic nationalisms and ethnic nationalisms, or between settler-colonial 
nationalisms and the nationalisms of the authentic or indigenous peoples.

History teaches us that the contradiction is not so much between good and bad nations, or good and bad nationalisms, but rather that the contradiction sits within each nationalism and each state. Sometimes anti-colonial nationalisms, founded in struggles for freedom, have become racist, ethnic, and exclusive. Sometimes civic nationalisms have decayed into ethnic nationalisms. Sometimes ethnic nationalisms have galvanized communities into just revolt against ostensibly civic states, which in reality oppress them. And perhaps a more profound truth is that there is no pure civic nation free from ethnic characteristics, and there is no oppressed nation that does not also contain a potential threat to its own minorities or to some of its neighbours.

Although Resolution 3379 was later rescinded, the essentialist understanding of Zionism as racism persists. The hostile use of the word "Zionism" continues to reflect the meaning of that 1975 resolution, a meaning that gained new life at the United Nations World Conference against Racism, in Durban, in 2001, and its three successor conferences. This characterisation of Zionism creates and legitimizes ways of thinking that cast Jews as evil, even if there are notional exemptions for exceptional Jews. Those ways of thinking are antisemitic.

\section{WHAT IS ZIONISM REALLY, IF IT IS NOT RACISM?}

Jews define their own Zionism in many different ways but essentially none of them define their own Zionism as racism. That is not how Zionists, even in their huge diversity, define, or have ever defined, Zionism. And it is not among the ways in which the overwhelming majority of Jews describe their own relationships to Israel.

For some, Zionism was a radical political response to antisemitism in the Middle East and in Europe; a movement inspired by other nineteenth-century national and twentieth-century anti-colonial movements, a movement for Jewish self-determination, to build a Jewish capacity for self-defence against antisemitism. For them, Zionism was a national liberation movement.

For some, Zionism describes a profound connection to the state of Israel as it exists today, not particularly to what it says or does, but to what it is; to its reality as a Jewish project of survival and rebirth; to its existence and its intention to exist into the future.

Most Jews today do not live where their families lived a hundred years ago; most families did not choose to move but were driven out. Most of them did not choose where to go, they went where they could. Jews outside Israel are connected to Jews inside Israel. Their families might have ended up there, and some of their family generally did.

For some, Zionism is in part a religious and a mystical yearning. The Torah, the Jewish story that is read weekly and repeated annually in synagogues, is set in and around the land of Israel. The places where those stories happened exist. The stories of slavery and liberation, exile and homecoming, the stories of who Jews were, and who they were becoming, relate to Israel.

For many Israelis, their Zionism is simply the citizenship of the country in which they were born and in which they live. Israel is a nation state, not an idea and not a movement. It just exists. It is not right or wrong. It does good things and it does bad things. Their greatgrandparents were Zionists, they sat around campfires learning Hebrew and planning to go to Israel, but their descendants are just citizens of a state.

Some Zionists are highly critical of recent governments of Israel; some have opposed the settlement projects in the West Bank with passion; some understand the Jewish settlements as unjust and unwise and as disruptive of the possibility of Israel living at peace with its neighbours; and some feel that the settlements constitute a betrayal of the core democratic values of their Zionism.

Others feel differently. For example, some, descended from Jewish families who lived for many centuries in Hebron before they were driven out by a campaign of murder and terror 
culminating in August 1929, believe they have a right to live there again. Some believe that they should act on that right. Some are supportive of the government's fierce and uncompromising defence of the Jewish minority in the Middle East, which has survived three wars of annihilation, and which keeps an eye on the armed antisemitic movements in neighbouring territories.

\section{MANY JEWS WARM TO SOME OR ALL OF THESE ZIONISMS}

Some people feel that Zionism is really a selfliberation movement for Jews, like feminism is a self-liberation movement for women. Others feel that non-Jewish people can be Zionist, like men can be feminist. Some kinds of non-Jewish Zionism are motivated by an impulse to ally with Jewish survival and self-defence; others are founded on conceptions of Jews and of Israel with which not every Jew or Israeli is likely to identify.

There is racist Zionism and there is racism in Israel. Antizionism takes one extreme thread of Zionism and treats it as the whole. The existence of racist Zionism is not what makes Zionism unique, it is what makes it like every other nationalist movement on earth.

\section{LOYALTY TESTS AND HOSTILE ENVIRONMENTS}

During the conflict between Israel and Hamas in May 2021, petitions were circulating widely amongst academics by which they affirmed their beliefs that Israel is apartheid, that they support BDS, that narratives of "both sides" 15 are pro-Israel propaganda, and that for Palestinians to be free Israel must be destroyed. These specific claims were explicitly spelt out as being foundational both to the scholarship and also to the morality of the academics, and the academic institutions, which signed these statements of "solidarity." 16

These statements function as loyalty tests that are likely to impact Jews specifically. If a person cannot make the required affirmations, then it follows that they are thereby defined as neither genuine scholars, nor moral people. The loyalty test is easy to pass for many people, just by signing up to some principles that seem to be antiracist, and that are affirmed by the good people around them. But for most Jews, they set up an impossible barrier.

Nazism was an unusual form of antisemitism because it did not allow Jews to convert, or to assimilate to the antisemitism. Yet Jews who had been allowed, by previous antisemitisms, to have exceptional status as being acceptable, were frequently still viewed with suspicion and were, in many practical ways, still excluded from the community, nevertheless. Conversos who survived the Spanish inquisition by converting to Christianity, for example, were still widely viewed as pariahs, and this often persisted down the generations. Pork was added to food, to see if they would eat it, and their chimneys were watched on Shabbat, to make sure that they had no objections to building and lighting a fire.

In May 2006, forerunner of UCU passed a motion calling for a "boycott of those that do not publicly dissociate themselves from Israeli governmental policies towards Palestinians." Steve Cohen felt this as a loyalty test for Jews, and he tried to show how this resonates specifically with Jewish experiences of antisemitism:

The significance is the assumption of collective responsibility, of collective guilt. Intrinsic to this is the requirement to grovel. Groveling, the humiliation of Jews, is fundamental to all anti-semitism. Degradation ceremonies are central to Jew-hatred. Remember those shocking images of Nazi Berlin where rabbis were forced to scrub pavements . . . being a squealie, a snitch, an informer, has always been seen within the Jewish tradition as being an abomination-particularly where the victim of denunciation is another Jew. For what it is worth (and culturally it is worth a lot) it says in Genesis "Though they all be killed they shall not betray a single soul from Israel". ${ }^{17}$ 


\section{DEFINING "ZIONISM" AS APARTHEID}

This paper now turns to a more detailed look at the analogy between Israel and apartheid South Africa. The discussion begins with some consideration of the difficulties of interpretation, which are often important in making judgments about understanding rhetoric held to express contemporary racism and bigotry in general, and no less about contemporary antisemitism.

It is plausible to argue that in some senses racism and xenophobia are on the rise around the world, especially within political discourse related to populism, and associated to what is sometimes called the "culture wars." The counter-argument would point to the ever-wider acceptance of cultural prohibitions of racism, sexism, and homophobia, and other such injustices.

One way in which this contradictory situation might operate is through rhetoric that can be interpreted differently by different listeners. President Trump, for example, used the phrase "bad hombres" in a Presidential debate in 2016. His supporters understood him to be promising to bear down on Mexican criminals entering the United States, while his opponents were certain that they could hear an implicit racist slur against Americans of Mexican origin in general. He used the phrases "nasty woman," "Kung Flu," and "complete shutdown of Muslims entering the United States" in similar ways. Bigoted rhetoric often appears in ambiguous and deniable form. It can be interpreted one way by supporters, another way by people who are not thinking about things in any great depth and who do not know much about them, and a third way by opponents, and people who may feel targeted by the rhetoric.

Contemporary antisemitism tends to take similarly ambiguous and deniable forms. What does "Free Palestine" mean? What is the meaning of "Palestine will be free, from the river to the sea"? What does it communicate when somebody waves a Palestinian flag? These are widely interpreted as unobjectionable, virtuous statements of hope for freedom and independence.
But they can also be interpreted as symbols of support for the military defeat of Israel and for the mortal danger to Jews, which would predictably follow. Context may be key. If "Free Palestine" is written on the door of a synagogue in Norwich ${ }^{18}$ or in Los Angeles, ${ }^{19}$ then it will be interpreted as a threat towards local Jews - and the threat is not limited to local "Zionists." If the Palestinian flag is flown from a car driving through a Jewish neighbourhood and men in the car are threatening sexual violence against Jewish, not "Zionist," women, through megaphones,$^{20}$ the meaning of the flag changes.

On the other hand, if a Palestinian flag appears in an image with an equal Israeli flag, then it is likely to be interpreted as support for peaceful coexistence between the two nations. But such images, and the worldviews they represent, are increasingly being denounced as "Zionist." The peace process itself is denounced as part of the ideological and material infrastructure of racist occupation, genocide, and oppression.

None of this is to say that there is something inherently antisemitic about the symbols of a free and sovereign Palestine. Many Jews and many Zionists passionately and publicly support the creation of a free and sovereign Palestine. Yet still, in the complexity of actually existing antizionist movements these symbols may be understood to communicate antisemitic meaning.

There is an ambiguity, a built-in capacity for double meaning, in the analogy that is often made between Israel and apartheid South Africa. Of course, everything is similar to everything, and everything is different from everything else, so the force of analogy is always debatable. It is necessary to make a judgment about what is at stake in the way an analogy is being used.

There was a 2005 book called Seeking Mandela: Peacemaking between Israelis and Palestinians. ${ }^{21}$ The book supported a peace between Israel and Palestine based on coexistence and aimed to learn from the experience of peaceful transition out of apartheid in South Africa. It is possible to make analogies between 
Israel and South Africa in thought-provoking and enlightening ways.

But the analogy is generally used in another context and in the service of another politics. It is used to communicate the idea that Israel is racist in its essence and so must be destroyed. The boycott of South Africa lives on in the collective memory of the global Left, sometimes as having been more decisive than it in fact was in ending apartheid. Perhaps it is remembered as the Left's last great victory. The identification of Zionism with apartheid associates this present struggle with that one, and it functions as a shortcut to support for a boycott of Israel.

The idea of apartheid in South Africa, and the apartheid state that actualized that idea, was essentially racist. There was no question of reforming apartheid so that it was no longer racist, because apartheid was a form of racism and the apartheid system built upon it reflected that. The anti-apartheid movement conceived of a new South Africa, which would not be racist in the explicit and legalised sense of apartheid. The aim was to create a not-apartheid South Africa in which racism may persist in the ways that it persists elsewhere, but in which racism was a violation of the dominant culture, norms, and laws of the new state. A new nation would be brought into being by the new political settlement and by a new set of inclusive institutions, which could constitute the new state, which would endow every person in the territory as an equal citizen, irrespective of "race." And then, in this normalized situation, with apartheid having been abolished, antiracists could continue to bear down on the racism that still existed in an effort to wipe it out altogether.

Antizionism insists that Zionism is racist in its essence, like the idea of apartheid was racist, and that the state of Israel in the territory antizionism calls "Palestine" is racist like the apartheid state in the territory of South Africa was racist. Just as the apartheid state was an evil, which could not be reformed, so antizionism says, Israel is an evil, which cannot be reformed. It must be destroyed, like apartheid was destroyed, and replaced by some kind of new state in the territory of Palestine. The new Palestinian state, one would assume, must be built on democratic principles like those of the new South Africa. It must therefore guarantee democracy, the rule of law, and security for the different ethnic and religious communities within the territory of the new rainbow Palestine.

One only has to work the analogy through carefully to see it break down. The African National Congress (ANC) in South Africa defined itself as a representative institution empowered to speak for the whole nation, the nascent new South Africa, even before it formally came into being in a relationship to the new state. In 1955, the ANC, following a widespread consultative process throughout South Africa, published the Freedom Charter. The Freedom Charter was a clear statement that the nation intended to replace apartheid racism with a non-racial, democratic South Africa. It was a guarantee, given in advance in particular to the white minorities, that the black majorities would not reverse the polarity of the injustice, which was perpetrated against them, and perpetrate a new injustice against minorities in the future.

There was of course political diversity in South Africa. There were ethnic or tribal nationalisms, such as that of the Inkatha Freedom Party; there were diverse traditions of Marxism; there was Black Consciousness politics. But in the end, the ANC, led by Nelson Mandela, was successful in asserting its leadership. It created a strong consensus and enduring consensus amongst South Africans that Mandela spoke for them. He successfully pursued a strategy of peacefully negotiating the end of the apartheid state and creating a new, democratic, nonracial state.

Palestinian politics is not similar. The reason for this is that the conflict between Israel and its neighbours is not similar to the common struggle against apartheid in South Africa. In South Africa, the Population Registration Act (1950) categorized people into racist categories at birth: "black," "coloured," and "mixed." 
"Indian" was added later. These categories determined a person's legal status and their life chances in hugely significant ways, as well as in ostensibly petty but symbolic and humiliating ways.

In the end, apartheid in South Africa turned out to be surprisingly brittle or fragile, although that is not to minimise the violence, injustice, and cruelty perpetrated by it during the five decades that it ruled. In the face of the mass united democratic movement, opposed by the non-racial trade unions, condemned by international solidarity campaigns, abandoned by the anti-communist support it had relied upon during the Cold War, the apartheid system was ready, by the 1990 s, to negotiate its own abolition. As though to illustrate Max Weber's understanding of stratification, the new black elite took political power, the white elite kept its money, and they traded status according to politics and wealth. Part of the deal was that there would be no trials for crimes committed by the apartheid state. The white elite insisted that its legal immunity was a deal-breaker.

Apartheid was fragile because it was literally an evil racist state, lording it over the majority, without any legitimating ideology, and so reliant only on pure power. In a modern economy, capital makes more money relying on free labour than it does relying on apartheid coercion.

Israel is not fragile, and it is not brittle. It will not negotiate itself away. Because it is not similar. Israel is a nation state. It could, it has tried, to negotiate a peace with the Palestinians by which they also became a nation state. But Israel will never negotiate itself out of existence. Israel is a home for people who found that they could not rely on non-Jews around them to defend their legal or moral rights. It is a home for the survivors of European antisemitism and the Shoah, for Jews who were ethnically cleansed from the great cities of the Middle East, and it is a home for the Jews who were erased by Stalinist Communism, which used a fake image of them to help people imagine the "enemy of the people." It is also a home to Jews who have lived there without interruption since biblical times, surviving waves of anti-Jewish hostility, not least the crusades.

Israel is not a fragile racist imperialist racket for rich white people to exploit the labour of black people. One of the founding ideals of a significant tradition of left-wing Zionism was that it would rely on Jewish labour, not on exploiting the labour of others. As things actually developed, the twenty-percent Arab minority in Israel does in fact participate in the economy. There is racism against this minority, but it is fundamentally the kind of racism that exists in every democratic state, it is not some kind of unique essence of the place, or some kind of apartheid. There are Arab judges, police, doctors, academics, lawyers, and politicians, as well as Arab farmers, craftsmen, labourers, taxi drivers, and factory workers. It is possible that as I write, a political party that defines itself as "Arab," overwhelmingly voted for by Arabs with Israeli citizenship, is playing a decisive role in a coalition that could end Benjamin Netanyahu's tenure as prime minister.

In Israel, anti-racists fight against racism and racists perpetuate it, much as things happen everywhere else. The problem in Israel is not apartheid and there is no essential racism within the soul of Zionism. The problem is the conflict between Israel and Palestinians. There are two nations competing over land. This is not a conflict about a system of colonial exploitation like there was in South Africa. The possible peace is a two-state solution and mutual recognition. It is about two nations; it is not a question of democracy for individual citizens. Israel is not an evil, fragile, racist state, ruling over others. It is a nation state.

The recent conflict was between Israel and Hamas, which is the political movement that rules in Gaza. If Israel was so similar to South Africa, why is the Hamas Charter ${ }^{22}$ so different to the Freedom Charter? The Hamas Charter is explicitly antisemitic, a merger of the worst of the European and the Middle Eastern antisemitic traditions. It is literally a movement 
explicitly founded on a programme to kill the Jews of Israel. Hamas was founded in order to prevent a successful negotiation between the Palestinian Authority, headed by Palestinian President Yassir Arafat, and Israel. The Hamas charter states clearly that making peace with Israel is a violation of a fundamental religious principle.

Hamas is a powerful and significant faction in Palestinian politics. It is plausible that the Palestinian Authority cancelled the scheduled Palestinian elections in May 2021 because Hamas was likely to win. Hamas does not aspire to replace "apartheid Israel" with a democratic secular state in the whole of Palestine. Hamas wants to kill the Jews and to institute a Palestinian Islamic state according to its own authoritarian and profoundly anti-democratic political principles. Some people argue that the Charter and the principles of the movement do not define the whole reality of Hamas, which may become, if it has the chance, a pragmatic Palestinian leadership, which could make peace with Israel. For sure, there is a Palestinian nationalist thread within Hamas, as well as an antisemitic and fundamentalist thread. But whether Hamas wants to kill the Jews and "recreate" the Caliphate, or whether it really could end up making a peace with Israel, the situation, the politics, or the aspiration is not similar to that of South Africa. Hamas will either smash Israel or it will make peace with it. A new Palestine, like the new South Africa, in which Jews are safe is not a possible outcome.

It may be objected that it is Fatah, the PLO, and the Palestinian Authority, taken together, which is the genuine analogue of the ANC here. It is true that this political tradition did eventually, in the 1980s, come to a formal position, which recognised Israel, and it did enter into negotiations with Israel about a peace agreement. But it was not able to sign and execute the peace agreements that were on the table in 2000 and in 2001; agreements in which Israel agreed to withdraw from nearly all of the West Bank and Gaza, and in which Israel proposed to support the creation of a sovereign Palestinian state. It is also true that this tradition, for the whole history of Israel until the 1980s, held a formal position of driving the Jews out and establishing a Palestinian state.

And terrorism, such as the attack on the Israeli Olympic team in 1972, such as plane hijackings, such as the Lod airport massacre, was part of this tradition. This tradition is not analogous to the ANC's "armed struggle," turned to campaigns of sabotage in the 1960s, which were careful to avoid loss of life, and which were later abandoned because inclusive and democratic methods were better.

In any case, Palestinian politics has always either aspired to wage war on Israel and to defeat it, or to recognize it and live alongside it. The "democratic secular state" slogan was always utopian. A democratic secular state would either come about with the consent of Israelis, therefore sometime in the very distant future, or it would come about without their consent, by conquest, in which case neither democracy nor secularism would be plausible outcomes.

If the hope for the South Africa analogy is that it can help people understand Israel's conflicts with the Palestinians, with states that define themselves as "Arab," with the specific political and religious movement of Shia Islam, which is led by the Iran regime of the Ayatollahs, and with a significant tradition of the global Left, then the South Africa analogy does not do well.

What the South Africa analogy actually achieves is to communicate the idea that Israel is a racist and evil entity, which must be boycotted and destroyed, as the apartheid state in South Africa was boycotted and destroyed.

\section{ANTIZIONIST NOSTALGIA FOR A PRE-HOLOCAUST AND PRE-ISRAEL WORLD}

Nostalgia is a yearning for a world that never really existed. Contemporary antizionism, led by Jewish antizionism, bases itself in a utopian fantasy of Jewish suffering. It loves to remember 
Jews who were oppressed but radical, powerless but smart and sardonically funny, influential through their egalitarian thinking and their quiet courage. These cherry-picked fantasies are jarring to those who look at America today and see Jews as white, selfish, and privileged or who look at Israel and see Jews as militaristic, sadistic, and morally unsophisticated. The shame of this one-sided understanding burns hot. The sentimental nostalgia is related to reluctance to understand the hugeness of the actual changes that antisemitism, and responses to it, actually enforced on Jews.

Isaac Deutscher, Trotsky's biographer, who had been a Socialist Anti-Zionist before the Shoah, wrote the following in 1954, when he visited Israel:

I have, of course, long since abandoned my anti-Zionism, which was based on a confidence in the European labour movement, or, more broadly, in European society and civilization, which that society and civilization have not justified. If, instead of arguing against Zionism in the 1920s and 1930s I had urged European Jews to go to Palestine, I might have helped to save some of the lives that were later extinguished in Hitler's gas chambers. ${ }^{23}$

Deutscher was not embracing Zionism as an ideology, he was recognizing that the debate was over. Israel now existed in the material world and no longer just in the imagination.

Antisemitism treats "the Jews" as an idea rather than as a collectivity of actual human beings. Antizionism prefers to sustain "Zionism" as an idea than to recognise Israel as a nation state. An idea can be right or wrong, you can agree with it or you can disagree with it. A nation state just exists. Sometimes it does good things, sometimes it does bad things. But it cannot be destroyed without huge violence and injustice. However, it can hope to make peace with its neighbours.

Zionism was an idea but it became a nation state because of the epochal material changes that happened to Jews in Europe, in the Middle East, and in Russia in the twentieth century. A nation state cannot be born in sin and it cannot be evil in its essence. And it cannot be justly eliminated against its own will.

Israel could have come into being in other ways, but the Israel that came into being in the twentieth century, the Israel that exists, this Israel, came into being partly as a result of antisemitism. Israel's failure to make peace with its neighbours is partly a result of antisemitism. The symbolic importance of Israel in different cultures around the world is related to antisemitic traditions by which people are used to defining their own identities in relation to various imaginings of stories about Jews.

Antizionism has existed in the past as a way of thinking that was not antisemitic. It exists today, in the imagination of some antizionists, in the abstract, as a way of thinking that is not antisemitic.

But this antizionism, the one that exists, the one that relates to this Israel, the Israel that exists, the antizionism that constructs "Zionism" to be evil in its essence: this antizionism is, in our day, an ideology that demonizes Jews.

\section{REFERENCES}

1 Philip Klein, "Facebook Says Page Calling for Death to Jews doesn't Violate 'Community Standards,"' Washington Examiner, July 28, 2014, https://www.washingtonexaminer.com/facebook-says-page-calling-for-death-to-jews-doesnt-violate-community-standards?fbclid=IwAR0E143609|8k3JnbdpizxfZxPn8aD0GCEExn03k7iu2DwISx3gY0iCZ3_k.

2 Global Intifada, Facebook, November 21, 2018, https://www.facebook.com/WorldWidelntifada/ posts/2013243748973880. 
3 Justin Cohen, "Exclusive: Labour Suspends Councillor over Hitler and ISIS Posts," Jewish News, March 24, 2017, https:// jewishnews.timesofisrael.com/exclusive-labour-urged-to-suspend-councillor-over-hitler-and-isis-posts/.

4 Kian Sharif,, "Iran's Quds Force Commander Qaani Said in a Televised Speech Today that Israelis Should 'Go Back' to Their Homes in [. . ],"Twitter, May 29, 2021, https://twitter.com/KianSharif/status/1398512778063790080.

5 Ibrahim Ben Boutaba, Facebook image, May 6, 2019, https://www.facebook.com/photo.php?fbid=393787188142 $821 \&$ set $=$ g. $651872914834414 \&$ type $=1$ \& theater\&ifg $=1$.

6 Yehuda_Asajewski, “As @georgegalloway has shown us—with indefatigable passion—\#Zionists are not \#Jews. Thankfully, it's impossible to confuse Zionists with Jews, as [. . .]", Twitter, August 9, 2019, https://twitter.com/ YAsajewski/status/1159857721723805697.

7 Ayah Ali, "they try to portray Arab as 'Jew haters' but as long as you distinguish between a Jew and a Zionist [...]," Twitter, accessed August 12, 2021, https://twitter.com/ayahalina5/status/837887865640128512.

8 Colin Brown and Chris Hasting, "Fury as Dalyell Attacks Blair's 'Jewish cabal,"' The Telegraph, May 4, 2003, https:// www.telegraph.co.uk/news/uknews/1429114/Fury-as-Dalyell-attacks-Blairs-Jewish-cabal.html.

9 Paul Foot, "Worse than Thatcher," The Guardian, May 14, 2003, https://www.theguardian.com/politics/2003/may/14/ labour.politicalcolumnists.

10 Mir S, "Yes against Israeli Forces (not Jews) who are Committing War Crimes [. . .],"Twitter, May 23, 2021, https:// twitter.com/searotonin/status/1396402690893127682?fbclid=IwAR18dQgiNOJe6Quf-yHB5NJL3SPhL_qNKFAIYJKGug9H1Ap1AsDMYhw6SDI.

11 David Seymour, "Disavowal. Distinction, and Repetition: Alain Badiou and the Radical Tradition of Antisemitism," in Unity and Diversity in Contemporary Antisemitism: The Bristol-Sheffield Colloquium on Contemporary Antisemitism, ed. Jonathon G. Campbell and Lesley D. Klaff (Boston: Academic Studies Press, 2019), 203-218.

12 United Nations General Assembly Resolution 3379 (1975), "Elimination of All Forms of Racial Discrimination," November 10, 1975 (A/RES/3379 [1975]).

13 Judicial Service Commission of South Africa, "Response to the Statement by the South African Jewish Board of Deputies," May 4, 2021, https://www.judiciary.org.za/images/news/2021/Media_Statement_-_JSC_Response_to_ the_Statement_by_the_South_African_Jewish_Board_Of_Deputies.pdf.

14 Ntwaagae Seleka, "Attempts to Get Judge Unterhalter's ConCourt Bid Rejected 'because of Association with the Board,'"news24, April 15, 2021, https://www.news24.com/news24/SouthAfrica/News/judge-unterhalters-concourtbid-rejected-due-to-his-association-with-the-board-sajbd-20210415.

15 "Gender Studies Departments in Solidarity with Palestinian Feminist Collective," Gender Studies Palestine Solidarity, accessed June 5, 2021, http://genderstudiespalestinesolidarity.weebly.com/?fbclid=IwAR2lqflJgUvWDIVdyueNcWWIIYIY5IKGfHkktugWK96SXiDg3RYJlkikPyE.

16 For example, "Goldsmiths UCU \& Goldsmiths Students' Union Stand in Full Solidarity with the People of Palestine," Goldsmith UCU, accessed May 18, 2021, https://goldsmithsucu.org/2021/05/18/gucu-goldsmithsstudents-union-stand-in-full-solidarity-with-the-people-of-palestine/?fbclid=IwAR1CComibsgUOA9AZhAljutp96hob514MyARoxAii-dVm2VcEQYmiKcQu4A. Note: this statement has been taken down and currently appears in a shortened version with the text: "Please note that a longer version of this statement was previously posted here. We are in the process of clarifying details of that statement with Goldsmiths management." "Goldsmiths UCU \& Goldsmiths Students' Union Stand in Full Solidarity with the People of Palestine," Goldsmith UCU, May 25, 2021, https://goldsmithsucu.org/2021/05/25/goldsmiths-ucu-goldsmiths-students-union-stand-in-full-solidarity-withthe-people-of-palestine/. See also Palestine and Praxis, accessed June 5, 2021, https://palestineandpraxis.weebly. com/?fbclid=IwAR3aoOn_GADFt-PTnALePjlaoSqtCZ4TerRPwNrHfH9uKcOKKyeOc4MrZll.

17 Steve Cohen, "'I would Hate Myself in the Morning,"'Engage Journal, May 29, 2006, https://engageonline.wordpress. com/2006/05/29/i-would-hate-myself-in-the-morning-steve-cohen-may-29-2006/.

18 Josh Salisbury, "Messianic Synagogue Daubed with "Free Palestine" Swastika," Jewish News, May 14, 2021, https:// jewishnews.timesofisrael.com/norwich-synagogue-daubed-with-free-palestine-and-swastika/.

19 Aaron Bandler, "Los Angeles Synagogue Vandalised with 'Free Palestine,'F-Israel' Graffiti,', Jewish Journal, May 30, 2020, https://jewishjournal.com/los_angeles/316561/los-angeles-synagogue-vandalized-with-free-palestine-fisrael-graffiti/. 
20 "Convoy Tours North London with Speaker Shouting 'F**k the Jews, Rape Their Daughters,"' The Jewish Chronicle, May 16, 2021, https://www.thejc.com/news/uk/pro-palestinian-convoy-tours-north-london-with-speaker-shoutingf-k-the-jews-rape-their-daughters-1.516778.

21 Heribert Adam and Kogila Moodley, Seeking Mandela: Peacemaking between Israelis and Palestinians (Phladelphia: Temple University Press, 2005).

22 "The Covenant of the Islamic Resistance Movement," August 18, 1988, https://avalon.law.yale.edu/20th_century/ hamas.asp, accessed June 5, 2021.

23 Isaac Deutscher, The Non-Jewish Jew and Other Essays (London: Oxford University Press, 1968). 
